\title{
A boat hitchhiker's guide to survival: Cabomba caroliniana desiccation resistance and survival ability
}

\author{
Tobias O. Bickel
}

Received: 30 March 2014/Revised: 30 June 2014/Accepted: 11 July 2014/Published online: 5 August 2014

(C) Crown Copyright as represented by the Queensland Government 2014

\begin{abstract}
Cabomba caroliniana is a submersed macrophyte that has become a serious invader. Cabomba predominantly spreads by stem fragments, in particular through unintentional transport on boat trailers ('hitch hiking'). Desiccation resistance affects the potential dispersal radius. Therefore, knowledge of maximum survival times allows predicting future dispersal. Experiments were conducted to assess desiccation resistance and survival ability of cabomba fragments under various environmental scenarios. Cabomba fragments were highly tolerant of desiccation. However, even relatively low wind speeds resulted in rapid mass loss, indicating a low survival rate of fragments exposed to air currents, such as fragments transported on a boat trailer. The experiments indicated that cabomba could survive at least $3 \mathrm{~h}$ of overland transport if exposed to wind. However, even small clumps of cabomba could potentially survive up to $42 \mathrm{~h}$. Thus, targeting the transport of clumps of macrophytes should receive high priority in management. The high resilience of cabomba to desiccation demonstrates the risk of continuing
\end{abstract}

Guest editors: Sidinei M. Thomaz, Katya E. Kovalenko, John E. Havel \& Lee B. Kats / Aquatic Invasive Species

T. O. Bickel $(\bowtie)$

Invasive Plant and Animal Science, Department of Agriculture Forestry and Fisheries, Ecosciences Precinct, GPO Box 267, Brisbane, QLD 4001, Australia

e-mail: tobias.bickel@daff.qld.gov.au spread. Because of the high probability of fragment viability on arrival, preventing fragment uptake on boat trailers is paramount to reduce the risk of further spread. These findings will assist improving models that predict the spread of aquatic invasive macrophytes.

Keywords Cabomba caroliniana - Aquatic invader . Desiccation $\cdot$ Survival $\cdot$ Spread potential $\cdot$ Dispersal

\section{Introduction}

Human-mediated extra-range dispersal of organisms is currently significantly altering the global environment on an unprecedented scale (Vitousek et al., 1996). Once established, these invasive organisms frequently negatively impact the ecological integrity of their new environment (Mack et al., 2000). Species invasions are one of the top reasons for the global decline in biodiversity and cause a homogenisation of ecosystems (Rahel, 2007). Aquatic plants feature some of the worlds worst alien invasive species (AIS), such as water hyacinth (Eichhornia crassipes) (Lowe et al., 2000), and cause significant ecological, economic and social impacts (Lodge et al., 2006).

Dispersal of invasive organisms is the initial stage of a multi-layered invasion process and arguably a key stage at which management efforts should be directed. However, so far the role of dispersal in the invasion 
process is largely ignored in research (Puth \& Post, 2005). Dispersal pathways shape the invasive potential of introduced organisms and influence propagule pressure (Wilson et al., 2009), therefore, having a strong influence on establishment success (Lockwood et al., 2005). Consequently, managing dispersal pathways, mostly unintentional transport through boating in the case of aquatic plants (Johnstone et al., 1985; Johnson et al., 2001), is imperative to understand the dispersal of aquatic plants in the landscape and to create efficient management strategies.

We studied the invasive aquatic macrophyte cabomba (Cabomba caroliniana Gray: Cabombaceae) to investigate how desiccation affects survival during unintentional overland transport. Cabomba, or water fanwort, is a submersed aquatic macrophyte native to freshwaters of South and North America (Ørgaard, 1991). Introduced worldwide as a popular aquarium species, it became a serious aquatic invasive species in many countries including Australia, USA (outside its native range), Canada, the Netherlands and China (Ørgaard, 1991; Les \& Mehrhoff, 1999; Wilson et al., 2007; van Valkenburg et al., 2011; McCracken et al., 2013).

Cabomba is a significant aquatic weed in Australia, creating serious environmental impacts through its tendency to form large mono-specific stands that displace native vegetation, potentially altering entire ecosystems (Mackey \& Swarbrick, 1997; Hogsden et al., 2007; Wilson et al., 2007). Cabomba also causes serious economic and social impacts through interference with aquatic recreational and commercial activities, and results in high management costs. Although cultivation and sale of cabomba are now prohibited in Australia, the plant is increasing its naturalised range and could potentially establish in large parts of Australia with suitable habitat. Because we lack a good understanding of dispersal pathways of cabomba, it is difficult to anticipate future incursions.

Like most invasive aquatic macrophytes, cabomba predominantly reproduces through vegetative propagules (stem fragments) (Ørgaard, 1991), and humans are the main vector for dispersal (Wilson et al., 2007; Jacobs \& Macisaac, 2009). In particular, invasive macrophytes, such as cabomba, disperse and subsequently, establish through unintentional overland transport ('hitch hiking') by recreational boat trailers despite being exposed to desiccation (Johnstone et al., 1985; Johnson et al., 2001; Rothlisberger et al., 2010; Evans et al., 2011). The rate of arrival of viable fragments (propagule pressure) is directly linked to potential invasion success (Lockwood et al., 2009). In fact, the frequency of boat traffic alone is sufficient to predict interlake dispersal of aquatic invasive species in New Zealand with a high degree of confidence (Johnstone et al., 1985). The frequency of boat trailers that carry macrophytes can be surprisingly high. In one study, $33 \%$ of trailers leaving a boat ramp at Lake St. Clair were recorded of carrying macrophytes (Johnson et al., 2001). Similarly, $45 \%$ of boats inspected at boat ramps in Wisconsin and Michigan carried plant fragments (Rothlisberger et al., 2010). As cabomba has a high regeneration potential, even a small piece of stem with a single node has a regeneration probability of 50\% (Bickel, 2012), the arrival of a small number of stem fragments potentially create a large number of propagules (nodes) in a new environment.

The unintentional spread of aquatic invasive plants is a function of the regeneration ability of fragments, resistance to desiccation and the suitability of habitat conditions for successful invasion (Johnstone et al., 1985; Jacobs \& Macisaac, 2009). Desiccation of aquatic plant fragments through exposure to air affects their viability and subsequent ability to recover or colonise new habitats (Jerde et al., 2012). Therefore, the risk of viable material arriving is directly linked to the distance travelled (Johnstone et al., 1985), as prolonged exposure to air will increase the degree of desiccation which directly affects survival and fitness (Jerde et al., 2012; Barnes et al., 2013). However, how external factors, such as clumping or wind speed, affect desiccation rates is currently unknown (Barnes et al., 2013). Also, desiccation rates and survival abilities vary with plant species (Barrat-Segretain \& Cellot, 2007; Barnes et al., 2013). Cabomba is known to be relatively resistant to desiccation and can survive a prolonged drawdown (Dugdale et al., 2013), but we lack information on the specific desiccation rates and survival abilities of cabomba when transported overland. Therefore, we cannot accurately predict overland transport distances of viable material under varying environmental conditions.

These knowledge gaps limit our current understanding of dispersal pathways of invasive aquatic plants and have direct management implications. First of all, it prevents accurately estimating the potential dispersal distance. Second, a better understanding of desiccation under varying scenarios could be used to tailor more successful drawdowns to control nuisance 
Table 1 Overview of the experiments with number of fragments and time frames used

\begin{tabular}{|c|c|c|}
\hline Experiment & $\begin{array}{l}\text { Fragments } \\
N\end{array}$ & Desiccation range $h$ \\
\hline $\begin{array}{l}\text { Desiccation } \\
\text { survival }\end{array}$ & 280 & $\begin{array}{l}0,0.25,0.5,1,2,3,4,6,8,12 \\
\quad 16,32,64\end{array}$ \\
\hline Temperature & 330 & $\begin{array}{l}0.25,0.5,1,1.5,2,3,4,6,8,12 \text {, } \\
16\end{array}$ \\
\hline $\begin{array}{l}\text { Relative } \\
\text { humidity }\end{array}$ & 330 & $\begin{array}{l}0.25,0.5,1,1.5,2,3,4,6,8,12 \text {, } \\
\quad 16\end{array}$ \\
\hline $\begin{array}{l}\text { Exposure to } \\
\text { sun }\end{array}$ & 260 & $0.25,0.5,1,1.5,2,3,4,5,6^{\mathrm{a}}$ \\
\hline Wind speed & 370 & $0.25,0.5,1,2,3,4,5,6^{\mathrm{b}}$ \\
\hline Clumping & 600 & $\begin{array}{l}0.25,0.5,1,1.5,2,3,4,5,6,7,8 \\
\quad 12,14,25,30\end{array}$ \\
\hline
\end{tabular}

$\bar{a}$ Due to the short day length during winter, fragments were not weighed at 3,5 and $6 \mathrm{~h}$

b Three of the wind speed settings $\left(0,3\right.$ and $\left.15 \mathrm{~km} \mathrm{~h}^{-1}\right)$ were only measured from 0.25 to $5 \mathrm{~h}$

infestations of cabomba. Third, we will be better able to estimate the rate of arrival of viable material, and therefore propagule pressure to assess the likelihood of successful establishment in new environments. Fourth, we currently know little about how overland dispersal affects fitness of propagules. A better understanding of survival of overland transport will allow to model the spread of invasive aquatic macrophytes in the landscape and to design more effective monitoring and management plans. This study tries to address some of these shortcomings in current knowledge. In particular, I hypothesised that (1) viability of cabomba fragments will decrease with increasing mass loss, and (2) that temperature, humidity, wind speed, sunlight and clumping significantly affect desiccation rates of cabomba fragments.

\section{Materials and methods}

This study followed a two-tiered experimental approach. First, an experiment was conducted to determine survival and regeneration potential of cabomba fragments in relation to the degree of desiccation (determined as mass loss). Following this, experiments were conducted to determine mass loss under varying scenarios (e.g. different air temperatures) in order to predict survival periods under these conditions (see overview Table 1).
For all experiments, fresh cabomba material was collected from Lake Kurwongbah, southeast Queensland, Australia $\left(27^{\circ} 15^{\prime} 3.8^{\prime \prime} \mathrm{S}, 152^{\circ} 57^{\prime} 38.7^{\prime \prime} \mathrm{E}\right)$ prior to each of the experiments, stored in lake water and used within $48 \mathrm{~h}$ after collection. Visual healthy cabomba material was selected for uniform leaf size and internode distance and cut into $10 \mathrm{~cm}$ fragments ( $\sim 3$ nodes); no apical shoots were used to better represent a real world scenario where the majority of fragments created would not include an apical tip. Also, the fragments were standardised this way to reduce variability in desiccation rates (McAlarnen et al., 2012). Cabomba fragment wet mass was determined to the nearest $0.01 \mathrm{~g}$ after spinning cabomba material in a salad spinner until all excess water was removed. Subsequently, fragments were placed on a wire mesh that was fitted into trays to allow natural free air movement around the fragments, desiccated for a range of periods and re-weighed to determine mass loss (desiccation).

\section{Desiccation survival}

To determine the relationship between mass loss and survival of cabomba fragments, a minimum of ten fresh cabomba fragments each (280 in total) were dried for $0,0.25,0.5,1,2,3,4,6,8,12,16,32$ and $64 \mathrm{~h}$ at $25^{\circ} \mathrm{C}$ and $60 \%$ relative humidity in a temperature and humidity-controlled growth chamber (TRHL-460, Thermoline Scientific, Australia). This resulted in fragments with a wide range in the degree of mass loss. Mass loss was calculated as (original wet mass desiccated mass)/original wet mass and used as a measure of the degree of desiccation. The selected timeframes yielded cabomba fragments with a mass loss ranging from 0.07 to 0.96 .

Because free floating fragments have a low chance of establishment (own observation), fragments were planted in substrate to enable unbiased measurement of potential survival; i.e. the survival ability separate to establishment probability. Following desiccation, fragments were planted individually in $150 \mathrm{ml}$ pots filled with a fine sandy substrate $(\sim 1 \mathrm{~mm}$ grain size $)$ with $5 \%$ organic content (from alluvial top soil) and slow release fertiliser ( $1.5 \mathrm{~g}$ Osmocote per $\mathrm{kg}$ substrate), covered with a $1 \mathrm{~cm}$ layer of $1 \mathrm{~mm}$ sand to prevent nutrient leakage into the aquarium water. Pots were randomly assigned to aquaria filled with a culture solution suitable for cabomba growth (Smart \& Barko, 
1985). Aquaria had a $14 \mathrm{~h}$ light $-10 \mathrm{~h}$ dark cycle $\left(\sim 80 \mathrm{mmol} \mathrm{s}^{-1} \mathrm{~m}^{-2}\right)$, and temperature was maintained at $25^{\circ} \mathrm{C}$. The $\mathrm{pH}$ was regulated at $\mathrm{pH} 6.5$ through $\mathrm{CO}_{2}$ injection. After 25 days, pots were inspected for survival of desiccated fragments. Survival was determined as the regeneration of new cabomba shoots (rooted in the substrate) emerging from the original fragment. For each regenerated plant (excluding the original fragment), the number of stems was counted (density), the length of the longest shoot (canopy height) was measured to the nearest $\mathrm{mm}$ and final biomass (dry mass) was determined to the nearest $0.01 \mathrm{~g}$.

The relationship between survival of fragments and mass loss was investigated to determine three critical mass loss values: a minimum survival time $\left(\mathrm{LD}_{0}\right.$, maximum mass loss where $100 \%$ of the plants survive), point of $50 \%$ death $\left(\mathrm{LD}_{50}, 50 \%\right.$ of the plants survive) and the maximum survival period $\left(\mathrm{LD}_{100}\right.$, all plants dead).

\section{Effect of external factors on mass loss}

Five separate experiments were conducted to investigate the effect of external factors (temperature, relative humidity, wind speed, sun exposure and clumping) on cabomba desiccation rates. To measure rates of desiccation under varying scenarios, ten cabomba fragments were desiccated for each of a range of time frames (Table 1), the chosen intervals depending on the specific rate of desiccation encountered in individual experiments. Spun fragment wet mass was determined immediately before commencement of the experiments. After each time interval, mass loss was measured for each individual fragment to the nearest $0.01 \mathrm{~g}$. Mass loss was calculated as above.

In two separate experiments, fragments were desiccated at three temperature $\left(20,25\right.$ and $30^{\circ} \mathrm{C}$; at $60 \%$ $\mathrm{RH}$, no lighting) and three relative humidity scenarios (40, 60 and $80 \% \mathrm{RH}$; at $25^{\circ} \mathrm{C}$, no lighting) that were created in a temperature- and humidity-controlled growth chamber (TRHL-460, Thermoline Scientific, Australia). Growth chambers had mechanical air circulation to allow uniform temperature and humidity control. The chosen temperature and humidity range is representative of climatic conditions commonly encountered in Queensland, Australia.
To investigate effects of exposure to sun, cabomba fragments were placed on a wire mesh fitted into a tray and desiccated in either full sun or full shade created by a building structure on a calm cool day in mid June and a second time on a hot day in December. Temperature and light intensities were logged in 5 min intervals with data loggers (Hobo pendant temp/ light data logger, Onset, USA) and are reported in the results (Table 4).

To investigate the effect of wind speed $(0,3,6.5,9$, $15 \mathrm{~km} \mathrm{~h}^{-1}$; at $22^{\circ} \mathrm{C}, 60 \% \mathrm{RH}$, fluorescent lighting) on mass loss, cabomba fragments were hung in air currents generated by a household ventilator in a laboratory. Wind speed was measured to the nearest $\mathrm{km} \mathrm{h}^{-1}$ with a hand-held anemometer (AM-4200, Lutron Electronic Enterprise, Taiwan).

Finally, to investigate effects of clumping of stems on desiccation, cabomba fragments were aligned parallel to each other and tied into little bundles (1, 2, 5 and 10 stem bundles) and dried under controlled climatic conditions $\left(25^{\circ} \mathrm{C}, 60 \%\right.$ humidity, no lighting, mechanical air circulation) in a temperature- and humidity-controlled growth chamber (TRHL-460, Thermoline Scientific, Australia).

\section{Statistics}

All statistical analysis was conducted with $\mathrm{R}$ version 3.0.1 (R Core Team, 2013). Linear regression was used to investigate the relationship between mass loss after desiccation and final biomass, canopy height and stem density of the surviving established plants. Residual and qqnorm plots were inspected to assure that data met the assumptions for linear regression.

To analyse the mass loss rates over time under varying conditions, non-linear least-squares regression ( $R$ function $n l s$ ) was used to fit 3-parameter asymptotic exponential functions

mass loss $=a-b e^{-c \text { dessication time }}$

to the data.

Oven drying cabomba resulted in a mass loss of $93 \%$; the asymptotic parameter $(a)$ was set at 0.93 . Fit of the functions to data was assessed from the statistical output generated by $n l s$. Parameters $b$ and $c$ (slope) of the functions were deemed significantly different at the $P<0.05$ level if confidence intervals were not overlapping. 
To estimate the minimum survival time $\left(\mathrm{LD}_{0}\right), 50 \%$ survival $\left(\mathrm{LD}_{50}\right)$ and maximum survival times $\left(\mathrm{LD}_{100}\right)$, the fitted asymptotic exponential functions were rearranged as functions predicting desiccation time. Respective mass loss values determined for $\mathrm{LD}_{0}, \mathrm{LD}_{50}$ and $\mathrm{LD}_{100}$ from the first experiment were then entered into these equations to estimate survival times.

dessication time $=c^{-1} \ln \left(\frac{a-\text { mass loss }}{b}\right)$

\section{Results}

Relationship between survival and mass loss

Of 110 cabomba fragments with a mass loss up to 0.65 , only one single fragment (mass loss 0.48 ) failed to establish. Because there is always a chance that any fragment fails to establish, this single fragment was taken as an outlier; i.e. it was assumed that this instance of establishment failure was a random event unrelated to degree of desiccation. Therefore, 0.65 mass loss was determined as the maximum mass loss that cabomba fragments can tolerate without experiencing mortality $\left(\mathrm{LD}_{0}\right)$. At 0.75 mass loss, half of all cabomba fragments did not survive $\left(\mathrm{LD}_{50}\right)$ and, once plants lost more than 0.90 of their initial wet mass, there was not a single surviving fragment out of 75 fragments (minimum lethal mass loss, $\mathrm{LD}_{100}$ ). As a comparison, the mass loss of oven dried plants was 0.93 .

\section{Effect of desiccation on plant regeneration}

While mass loss did not affect survival probabilities until it reached 0.65 of the original wet mass, desiccation nonetheless did affect the regeneration ability of the desiccated fragments. There was a linear relationship between mass loss of propagules and the final dry mass of newly regenerated cabomba shoots (linear regression: $P<0.0001, r^{2}=0.95$; Fig. 1a). While cabomba fragments had a $50 \%$ chance of survival at 0.75 mass loss, the regenerated shoots achieved only about $5 \%$ of the mass of control plants. The reduction in shoot mass was a direct result of the linear decline in the number of shoots (density: linear regression: $P<0.0001, r^{2}=0.95$ ) and shoot length (canopy height: linear regression: $P<0.0001$, $r^{2}=0.96$ ) with increasing desiccation (Fig. 1b, c).
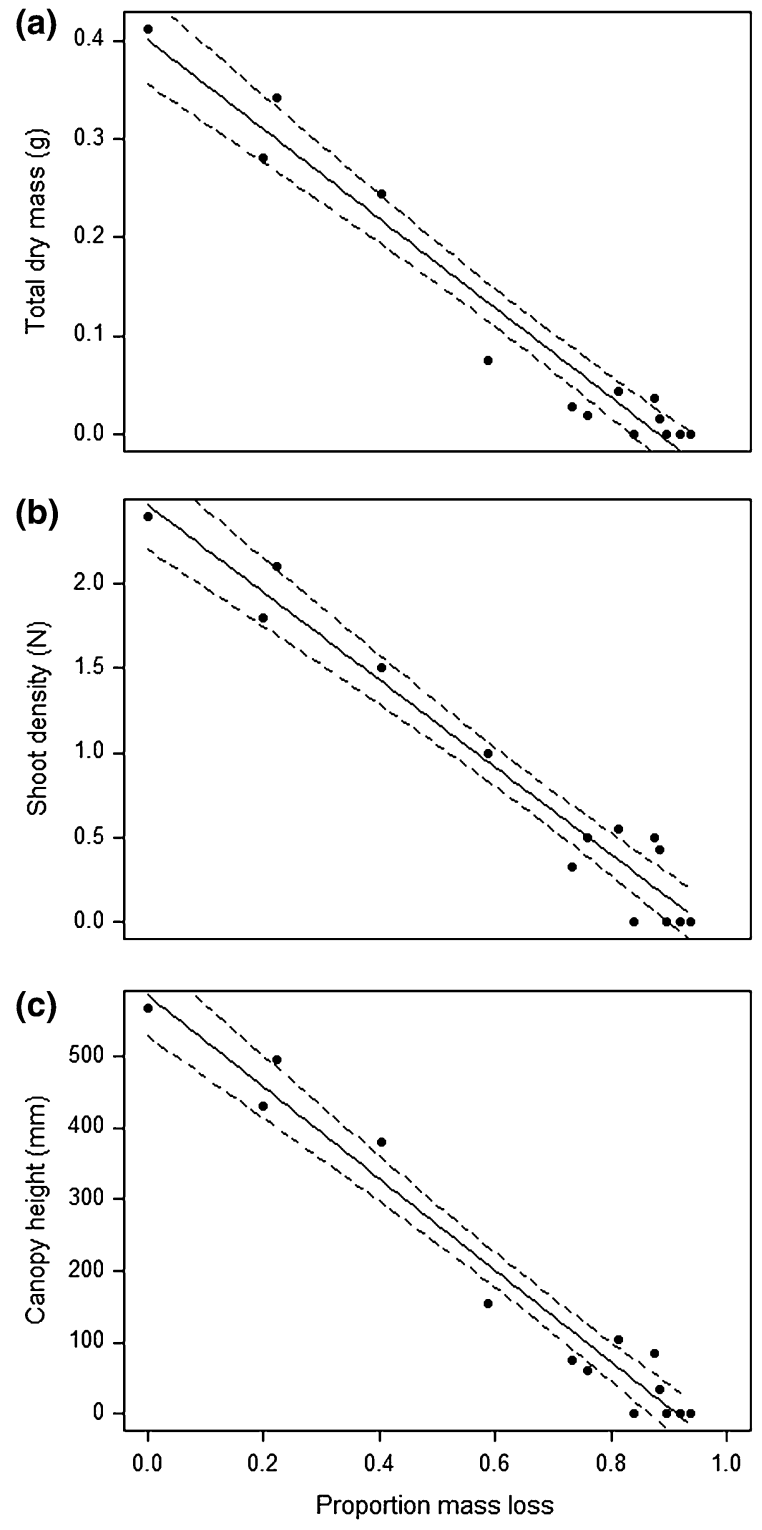

Fig. 1 The effect of desiccation (mass loss) on a the final dry mass of new shoots, $\mathbf{b}$ shoot density and $\mathbf{c}$ canopy height. The figures include linear regression lines (solid) and 95\% confidence intervals (dashed)

Effect of external factors on mass loss and survival periods

There was no significant effect of air temperature (20, 25 and $30^{\circ} \mathrm{C}$ ) on desiccation rates of cabomba fragments (Fig. 2). Irrespective of air temperature, cabomba fragments will survive for a minimum of 
Fig. 2 Mass loss of cabomba fragments at 20, 25 and $30^{\circ} \mathrm{C}$ (at $60 \% \mathrm{RH}$ ) with fitted exponential functions. Horizontal lines indicate $\mathrm{LD}_{0}, \mathrm{LD}_{50}$ and $\mathrm{LD}_{100}$ mass loss values

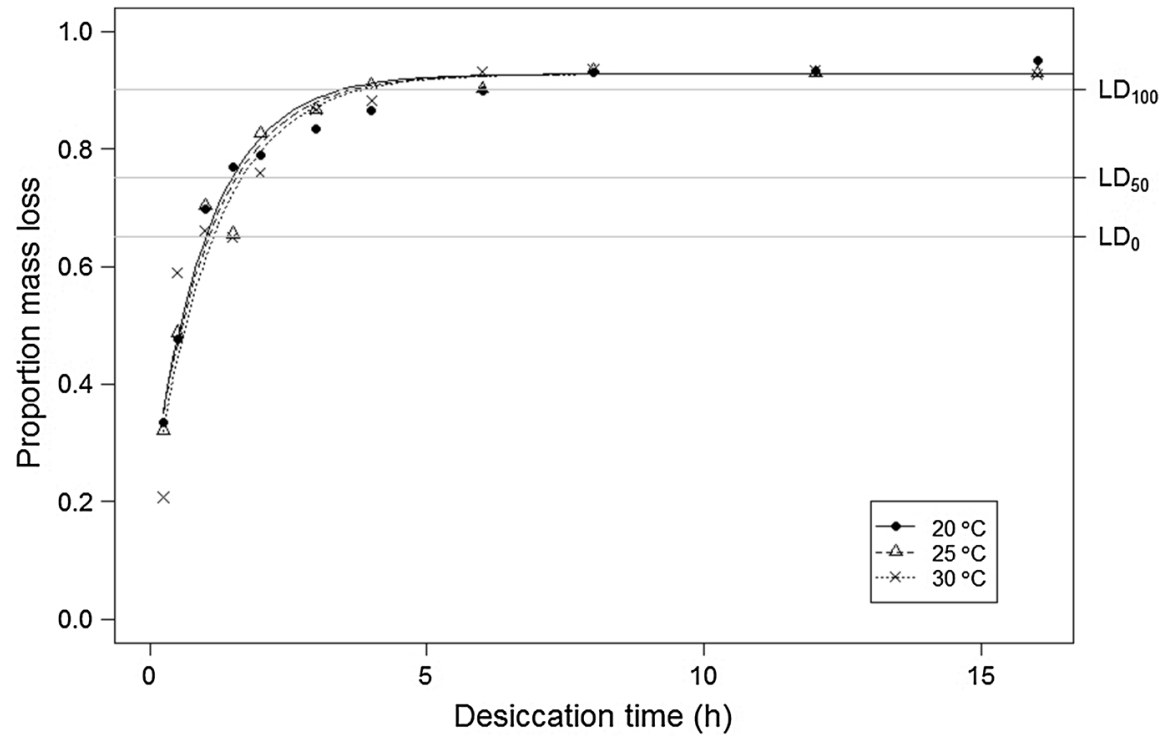

Table 2 Time (hours) to reach a mass loss resulting in $\mathrm{LD}_{0}, \mathrm{LD}_{50}$ and $\mathrm{LD}_{100}$ as influenced by temperature and parameter estimates for Eq. 1 with confidence intervals in brackets and the coefficient of determination

\begin{tabular}{lllllll}
\hline & $\mathrm{LD}_{0}$ & $\mathrm{LD}_{50}$ & $\mathrm{LD}_{100}$ & $b$ & $c$ & $r^{2}$ \\
\hline $20^{\circ} \mathrm{C}$ & 1.0 & 1.5 & 3.5 & $0.73(0.62-0.85)^{\mathrm{a}}$ & $0.95(0.72-1.24)^{\mathrm{a}}$ & 0.97 \\
$25^{\circ} \mathrm{C}$ & 1.1 & 1.6 & 3.6 & $0.72(0.60-0.86)^{\mathrm{a}}$ & $0.90(0.67-1.20)^{\mathrm{a}}$ & 0.97 \\
$30^{\circ} \mathrm{C}$ & 1.1 & 1.7 & 3.8 & $0.76(0.55-1.05)^{\mathrm{a}}$ & $0.87(0.51-1.52)^{\mathrm{a}}$ & 0.91 \\
\hline
\end{tabular}

Statistically significant differences between parameters at $P<0.05$ as indicated by lettering. All fitted parameters were significantly different from zero $(P<0.0001)$

Fig. 3 Mass loss of cabomba fragments for 40 , 60 and $80 \%$ relative humidity at a temperature of $25^{\circ} \mathrm{C}$

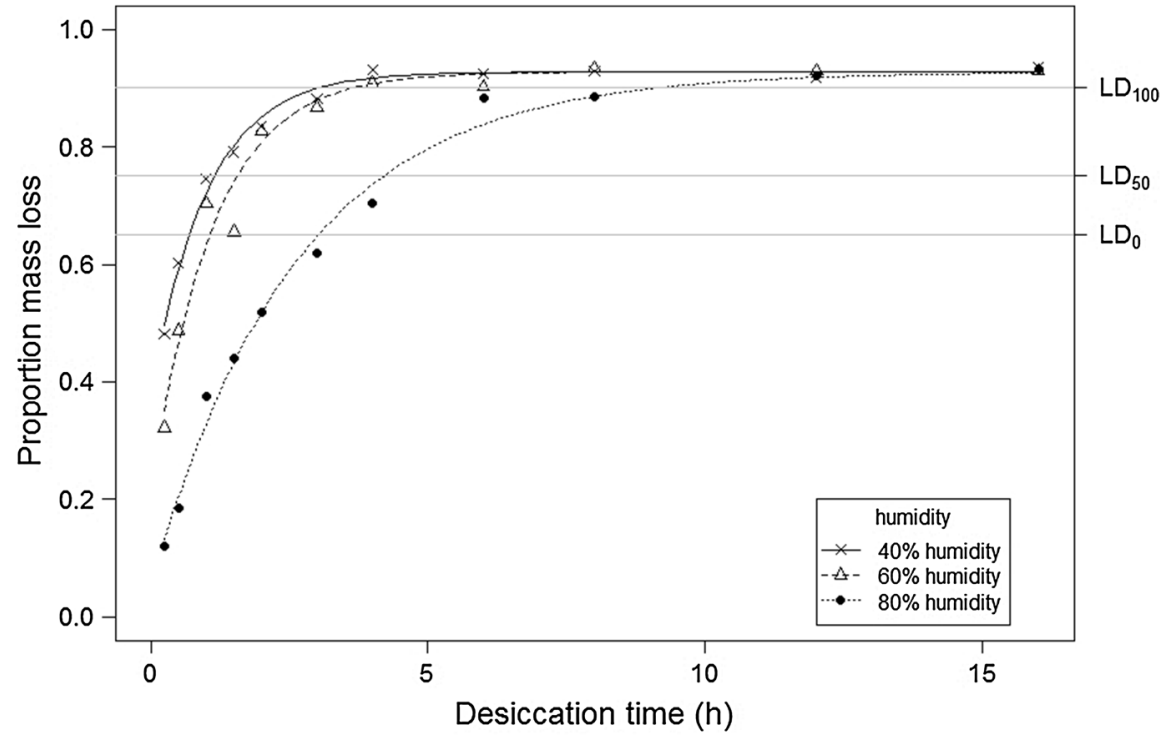


Table 3 Time (hours) to reach a mass loss resulting in $\mathrm{LD}_{0}, \mathrm{LD}_{50}$ and $\mathrm{LD}_{100}$ as influenced by relative humidity and parameter estimates for Eq. 1 with confidence intervals in brackets and the coefficient of determination

\begin{tabular}{lllllll}
\hline & $\mathrm{LD}_{0}$ & $\mathrm{LD}_{50}$ & $\mathrm{LD}_{100}$ & $b$ & $c$ & $r^{2}$ \\
\hline $40 \% \mathrm{RH}$ & 0.7 & 1.1 & 3.0 & $0.55(0.51-0.61)^{\mathrm{a}}$ & $0.99(0.51-0.61)^{\mathrm{a}}$ & 0.99 \\
$60 \% \mathrm{RH}$ & 1.1 & 1.6 & 3.6 & $0.72(0.60-0.86)^{\mathrm{ab}}$ & $0.90(0.51-0.61)^{\mathrm{a}}$ & 0.97 \\
$60 \% \mathrm{RH}$ & 3.0 & 4.2 & 9.1 & $0.88(0.82-0.93)^{\mathrm{b}}$ & $0.38(0.51-0.61)^{\mathrm{b}}$ & 0.99 \\
\hline
\end{tabular}

Statistically significant differences between parameters at $P<0.05$ as indicated by lettering. All fitted parameters were significantly different from zero $(P<0.0001)$

Table 4 Mean $( \pm \mathrm{SD})$ temperature and light intensities experienced by fragments placed in full sun or shade in winter (9:00-15:00 h) and summer (10:00-15:00 h)

\begin{tabular}{lllc}
\hline Season & Exposure & $\begin{array}{l}\text { Temperature } \\
\left({ }^{\circ} \mathrm{C}\right)\end{array}$ & $\begin{array}{l}\text { Light intensity } \\
(\text { Lux })\end{array}$ \\
\hline Winter & Shade & $23.2 \pm 1.4$ & $4,892 \pm 534$ \\
& Sun & $38.2 \pm 3.7$ & $86,400 \pm 50,097$ \\
Summer & Shade & $29.5 \pm 0.8$ & $4,476 \pm 1,635$ \\
& Sun & $42.8 \pm 5.5$ & $163,842 \pm 120,042$ \\
\hline
\end{tabular}

$\sim 1 \mathrm{~h}\left(\mathrm{LD}_{0}\right)$, and all fragments will reach a lethal mass loss $\left(\mathrm{LD}_{100}\right)$ at about $4 \mathrm{~h}$ out of water (Table 2$)$.

While air temperature did not affect desiccation rates of cabomba fragments, relative humidity had a pronounced effect (Fig. 3). Cabomba fragments dried out slower at $80 \%$ relative humidity as compared to 40 and $60 \%$. Resolving the fitted functions showed that minimum survival times were about $1 \mathrm{~h}$ for 40 and $60 \%$ humidity, but at $80 \%$ humidity fragments are expected to survive at least $2.7 \mathrm{~h}$ (Table 3). Higher air humidity $(80 \% \mathrm{RH})$ had a pronounced effect on the maximum survival times with a lethal mass loss only being reached after nearly $10 \mathrm{~h}$ as compared to about $3 \mathrm{~h}$ at lower humidity (40 and $60 \% \mathrm{RH}$; Table 3 ).

Temperatures and light intensities differed widely, both seasonally and between exposure to sun or shade (Table 4). While light intensities in the shaded treatment were similar in winter and summer, in the exposed treatment, light intensity in summer was nearly double of that in winter. Temperatures experienced in the shade were in the same range as those used in the temperature manipulation experiment, but surface temperatures in the sun exceeded these by more than $10^{\circ} \mathrm{C}$.

Cabomba fragments exposed to solar radiation dried out faster compared to shaded ones both in summer and in winter (Fig. 4; Table 5). The short day length in winter meant that exposure to sun was barely long enough to kill all cabomba. The shaded cabomba dried out so slowly in winter that some cabomba survived the maximum exposure period used in the trial. To estimate maximum survival time, the regression equation was extrapolated to $90 \%$ mass loss. In summer, cabomba fragments initially do dry out faster in the sun as can be seen from the different minimum survival times (Table 4). However, overall the maximum survival times were similar for shaded and exposed fragments in summer (1.7 and $2.6 \mathrm{~h})$.

Wind speed greatly increased desiccation rates of cabomba fragments (Fig. 5). Even at low wind speeds, minimum cabomba survival was estimated to be less than an hour and maximum survival times were $2-3 \mathrm{~h}$ (Table 6), while fragments in still conditions were expected to survive up to nearly $9 \mathrm{~h}$.

There was no difference in desiccation rates between single cabomba fragments and two fragments bundled together (Fig. 6). However, bundles of 5 and 10 fragments dried out considerably slower. Minimum survival times increased from $\sim 3 \mathrm{~h}$ for single fragments to $14 \mathrm{~h}$ for bundles of 10 fragments (Table 7). The largest bundles potentially could survive more than $42 \mathrm{~h}$.

\section{Discussion}

Cabomba fragments were found to be highly resistant to desiccation. There was a $100 \%$ survival probability for fragments that experienced a mass loss of up to $65 \%$, and some fragments were able to tolerate a mass loss of up to $90 \%$. This is remarkable, as a $90 \%$ mass loss is very close to oven dry weight ( $\sim 93 \%$ mass loss which is equivalent to losing $97 \%$ of the moisture it contained). These estimates of survival probability following desiccation are similar to those found in a 
Fig. 4 Mass loss of cabomba fragments in direct sunlight and shade during winter and summer. Exposure time was shorter in winter because of the shorter period of daylight

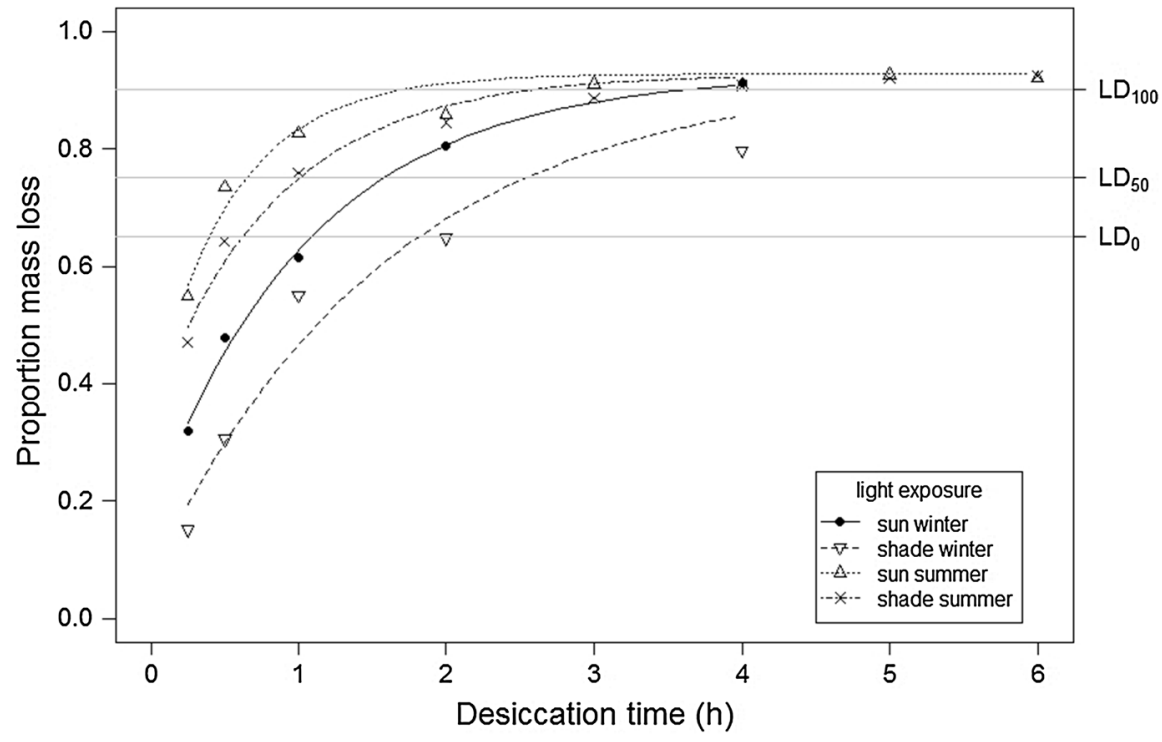

Table 5 Time (hours) to reach a mass loss resulting in $\mathrm{LD}_{0}, \mathrm{LD}_{50}$ and $\mathrm{LD}_{100}$ as influenced by exposure to sun light and parameter estimates for Eq. 1 with confidence intervals in brackets and the coefficient of determination

\begin{tabular}{lllllll}
\hline & $\mathrm{LD}_{0}$ & $\mathrm{LD}_{50}$ & $\mathrm{LD}_{100}$ & $b$ & $c$ & $r^{2}$ \\
\hline Sun winter & 1.1 & 1.6 & 3.6 & $0.75(0.66-0.84)^{\mathrm{a}}$ & $0.91(0.73-1.14)^{\mathrm{a}}$ & 0.99 \\
Shade winter & 1.8 & 2.5 & $5.5^{\$}$ & $0.86(0.62-1.20)^{\mathrm{a}}$ & $0.62(0.28-1.27)^{\mathrm{a}}$ & 0.91 \\
Sun summer & 0.4 & 0.6 & 1.7 & $0.56(0.37-0.92)^{\mathrm{a}}$ & $1.78(0.92-3.30)^{\mathrm{a}}$ & 0.91 \\
Shade summer & 0.6 & 1.0 & 2.6 & $0.58(0.47-0.73)^{\mathrm{a}}$ & $1.18(0.82-1.72)^{\mathrm{a}}$ & 0.95 \\
\hline
\end{tabular}

Statistically significant differences between parameters at $P<0.05$ as indicated by lettering. All fitted parameters were significantly different from zero $(P<0.0001)$

$\$$ Value extrapolated from function

Fig. 5 Effect of wind speed on desiccation of cabomba fragments

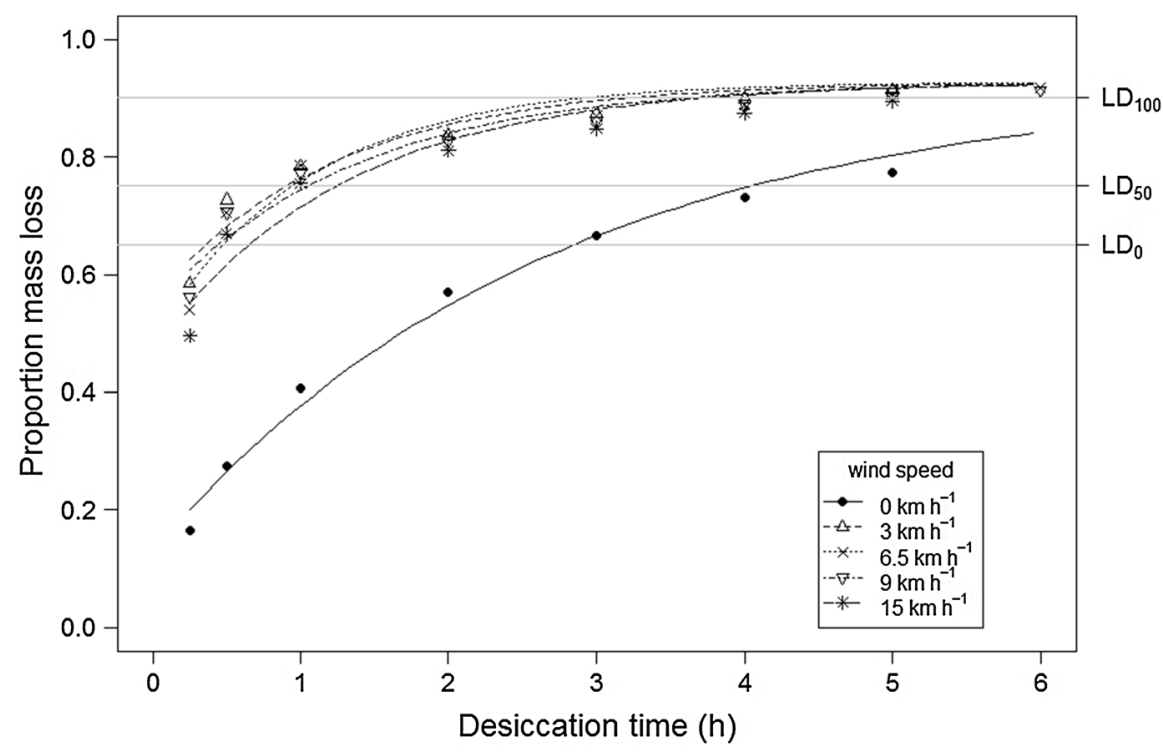


Table 6 Time (hours) to reach a mass loss resulting in $\mathrm{LD}_{0}, \mathrm{LD}_{50}$ and $\mathrm{LD}_{100}$ as influenced by wind speed and parameter estimates for Eq. 1 with confidence intervals in brackets and the coefficient of determination

\begin{tabular}{lllllll}
\hline & $\mathrm{LD}_{0}$ & $\mathrm{LD}_{50}$ & $\mathrm{LD}_{100}$ & $b$ & $c$ & $r^{2}$ \\
\hline $0 \mathrm{~km} \mathrm{~h}^{-1}$ & 2.8 & 4.0 & $9.1^{\$}$ & $0.80(0.74-0.86)^{\mathrm{a}}$ & $0.37(0.31-0.44)^{\mathrm{ab}}$ & 0.99 \\
$3 \mathrm{~km} \mathrm{~h}^{-1}$ & 0.4 & 0.9 & 3.2 & $0.37(0.27-0.55)^{\mathrm{b}}$ & $0.81(0.44-1.73)^{\mathrm{ab}}$ & 0.94 \\
$6.5 \mathrm{~km} \mathrm{~h}^{-1}$ & 0.5 & 0.9 & 2.9 & $0.44(0.31-0.69)^{\mathrm{b}}$ & $0.95(0.49-2.10)^{\mathrm{a}}$ & 0.92 \\
$9 \mathrm{~km} \mathrm{~h}^{-1}$ & 0.4 & 1.0 & 3.6 & $0.38(0.29-0.53)^{\mathrm{b}}$ & $0.74(0.43-1.43)^{\mathrm{ab}}$ & 0.91 \\
$15 \mathrm{~km} \mathrm{~h}^{-1}$ & 0.7 & 1.2 & 3.7 & $0.45(0.31-0.73)^{\mathrm{b}}$ & $0.75(0.37-1.86)^{\mathrm{ab}}$ & 0.91 \\
\hline
\end{tabular}

Statistically significant differences between parameters at $P<0.05$ as indicated by lettering. All fitted parameters were significantly different from zero $(P<0.0001)$

$\$$ Value extrapolated from function

Fig. 6 Effect of clumping on desiccation of cabomba fragments

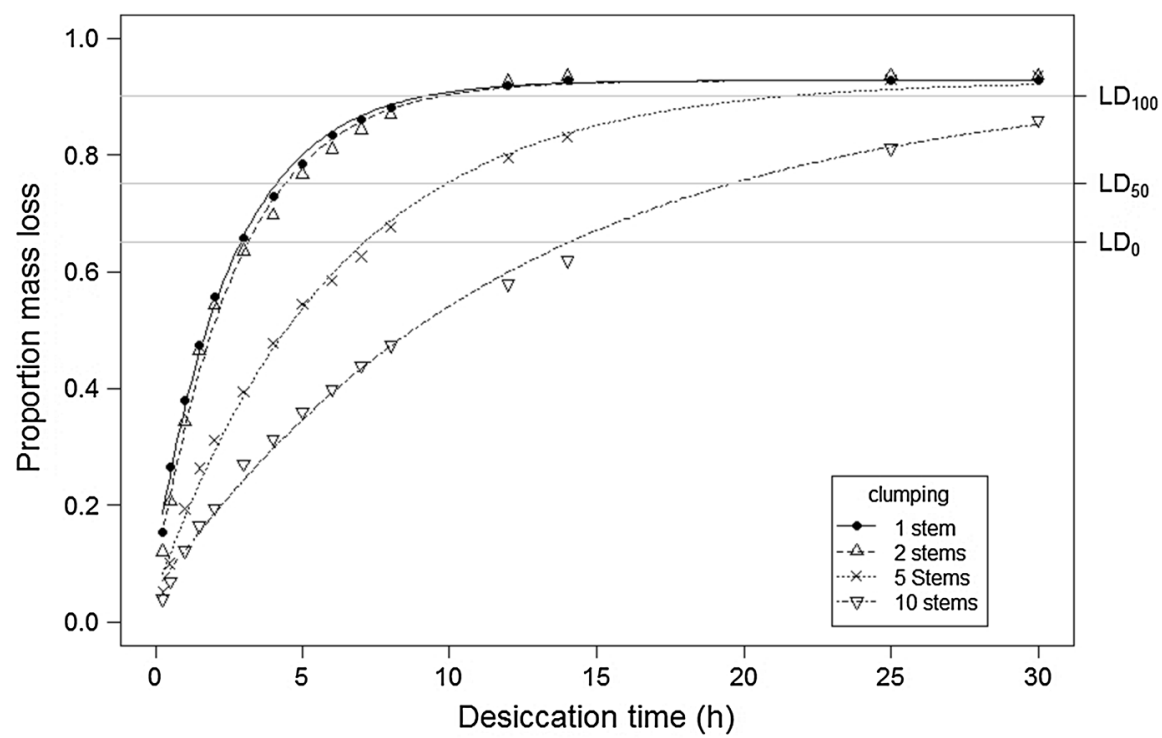

Table 7 Time (hours) to reach a mass loss resulting in $\mathrm{LD}_{0}, \mathrm{LD}_{50}$ and $\mathrm{LD}_{100}$ as influenced by clumping and parameter estimates for Eq. 1 with confidence intervals in brackets and the coefficient of determination

\begin{tabular}{lccclll}
\hline & $\mathrm{LD}_{0}$ & $\mathrm{LD}_{50}$ & $\mathrm{LD}_{100}$ & $b$ & $c$ & $r^{2}$ \\
\hline 1 stem & 2.9 & 4.1 & 9.1 & $0.81(0.79-0.84)^{\mathrm{a}}$ & $0.37(0.35-0.39)^{\mathrm{a}}$ & 0.99 \\
2 stems & 3.2 & 4.4 & 9.6 & $0.85(0.82-0.89)^{\mathrm{ab}}$ & $0.36(0.33-0.39)^{\mathrm{a}}$ & 0.99 \\
5 stems & 7.1 & 9.9 & 21.3 & $0.88(0.86-0.90)^{\mathrm{bc}}$ & $0.16(0.15-0.17)^{\mathrm{b}}$ & 0.99 \\
10 stems & 14.1 & 19.5 & $42.3^{\$}$ & $0.87(0.85-0.89)^{\mathrm{c}}$ & $0.08(0.08-0.09)^{\mathrm{c}}$ & 0.99
\end{tabular}

Statistically significant differences between parameters at $P<0.05$ as indicated by lettering. All fitted parameters were significantly different from zero $(P<0.0001)$

$\$$ Value extrapolated from function

study comparing several aquatic plant species (Barnes et al., 2013). Based on a logistic regression model, Barnes et al. (2013) estimated a 50\% viability at a mass loss of 0.58 and a $10 \%$ viability at a mass loss of
0.90 for Cabomba caroliniana. It is possible that survival rates of fragments that include an apical tip are potentially higher than the material that was used for the experiments here, similar to survival of 
Eurasian watermilfoil fragments (McAlarnen et al., 2012). Therefore, the survival times reported here can be considered a conservative estimate. However, as cabomba stems frequently reach several metres in length in nature, it can be expected that upon fragmentation, basal stem portions are numerically more abundant. Therefore, the materials used in the experiments reported here are representative of the majority of material expected to be found in the real world.

The found desiccation rates were best described by asymptotic exponential functions. Initially, cabomba fragments lost mass rapidly, but desiccation rates slowed down later. The reason for this is most likely that, initially, mass loss is the result of water evaporating from the plant surface and desiccation of tissue of the finely dissected leaves. The stems would be more resistant to drying. Ultimately, only the nodes need to survive for the plant to regenerate, making cabomba highly resistant to water loss. Because of cabomba's high regeneration potential (Mackey \& Swarbrick, 1997; Bickel, 2012), its survival from water loss is high.

While cabomba fragments survived up to $90 \%$ mass loss, increasing desiccation did reduce the ability of surviving material to produce new shoots. In fact, the regeneration ability of fragments declined linearly with desiccation. So while fragments are able to survive desiccation, they seem to lose the potential to regenerate healthy new plants with increasing moisture loss. Mass loss directly affected stem length, shoot density and total biomass of plants regenerating from fragments. These findings are similar to the effects of desiccation on fitness of Myriophyllum spicatum (Eurasian watermilfoil). Myriophyllum spicatum fragments also lost fitness with increasing desiccation (Evans et al., 2011; Jerde et al., 2012). The lower fitness of desiccated fragments directly influences propagule pressure, and therefore the probability of successful establishment in a new environment (Lockwood et al., 2005, 2009). Loss of fitness also means that the estimated survival times have to be seen as conservative estimates. While some cabomba fragments tolerated up to $90 \%$ desiccation, if loss of fitness is taken into account, fragments are unaffected by water loss only to about $40 \%$. The loss of fitness with increasing desiccation means that the risk of successful establishment decreases well before the maximum survival times are reached because a certain proportion of arriving propagules will not be able to fully regenerate.

There was a varied response of cabomba desiccation rates to external factors. While air temperature did not affect desiccation rates within the tested range, cabomba fragments desiccated slower at higher relative humidity, affecting both minimum and maximum survival times. At $80 \%$ relative humidity, predicted maximum survival times more than tripled from $3.1 \mathrm{~h}$ (at $40 \% \mathrm{RH}$ ) to $9.8 \mathrm{~h}$. This is not surprising as the higher water content in the air will slow down evaporation of water from the plant surface and tissue.

Exposure to solar radiation initially increased desiccation rates and reduced predicted minimum survival times. This was especially noticeable in summer with a reduction in predicted minimum survival times from $40 \mathrm{~min}$ in the shade to $12 \mathrm{~min}$ in the sun. However, maximum survival times did not vary that greatly. This might be because solar radiation initially increases evaporation of surface water from the plants, but has less effect on water contained in stems. In winter, cabomba fragments dried out considerably slower. With the shorter exposure periods $(4 \mathrm{~h})$, the shaded fragments actually never reached a mass loss causing LD100. Maximum survival times were estimated from extrapolating the regressions.

Of all the external factors investigated, wind speed had the most prominent effect on desiccation rates when measured in isolation. Even at low wind speeds, minimum desiccation rates were reduced drastically. Presumably, air currents carry away surface water more rapidly by interfering with boundary air layers, thereby increasing desiccation rates of fragments. While fragments sheltered from air currents had a maximum predicted survival time of nearly $9 \mathrm{~h}$, this was reduced to less than $3 \mathrm{~h}$ maximum survival when fragments were exposed to wind. This compares well to the viability of less than $3 \mathrm{~h}$ determined for $C$. caroliniana in an experiment that desiccated fragments in front of a fan similar to the setup used in this paper (Barnes et al., 2013). Cabomba fragments are regularly transported by boat trailers, and in some areas, this can be the major mode of spread for cabomba and other aquatic invaders (Johnstone et al., 1985; Jacobs \& Macisaac, 2009). The increased desiccation of fragments exposed to wind directly affects the potential radius that viable cabomba 
fragments can be transported by boat trailers. The air currents tested in the experiments were still fairly low compared to wind speeds that hitchhiking fragments might experience. However, while relatively low wind speed had a marked drying effect compared with still conditions, the desiccation curves were very similar for the wind speeds tested $\left(3-15 \mathrm{~km} \mathrm{~h}^{-1}\right)$. It can be hypothesised that desiccation of fragments at higher wind speeds follow a similar pattern. If this is the case, experiments indicate a maximum dispersal radius of about $3 \mathrm{~h}$ for fragments hitchhiking on boat trailers. Also, it should be considered that, while boat trailers travel at much higher speeds than tested in this study, not all areas of a boat trailer where fragments could be attached will be exposed to high wind speeds. Some fragments might hitchhike in areas that are sheltered, and therefore experience reduced wind speeds relative to the actual speed of travel. Therefore, I consider the estimated maximum survival times of cabomba fragments transported on boat trailers to still be relevant.

After wind speed, clumping was another important factor affecting desiccation rates of cabomba fragments. Clumping means that fragments that are in the centre of a clump are sheltered and lose water more slowly than fragments located on the clump 'surface'. Even the fairly small cabomba clumps used in this experiment greatly increased survival probability of fragments. The minimum survival times increased more than fourfold, and maximum survival was estimated at around $42 \mathrm{~h}$. This time period would allow cabomba fragments to potentially be transported over considerable distances. Additionally, mass loss was measured as an average over all fragments that made up a clump. Fragments in the centre of a clump would have had a lower mass loss than the average, and their survival times would have been underestimated. In larger clumps than used here, potentially viable fragments could persist well beyond $50 \mathrm{~h}$.

The number of factors affecting desiccation meant that experiments could not be carried out in a crossed statistical design. Therefore, it was not statistically possible to predict how a combination of factors affected fragment survival. However, considering that survival was primarily affected by only three factors (wind speed, clumping and relative humidity), it can be assumed that cabomba fragments should be able to at least survive three hours as a hitchhiker on a boat trailer. However, in a worst case scenario where cabomba clumps are protected from air currents, for example in anchor wells of boats, cabomba could survive much longer transportation periods.

These estimated survival times have direct management implications. Because of the resistance of cabomba fragments to desiccation and their high survival ability, the risk of cabomba spread between water bodies is high. Current models of aquatic plant dispersal predominantly consider short distance transport events between geographically close water bodies. However, the long-term survival of clumped stems means that cabomba can potentially be spread over much greater geographical distances. As we cannot influence survival rates of transported material, the prevention of uptake of viable material, in particular in the form of clumps, is paramount to prevent further spread of cabomba.

The high desiccation resistance explains difficulty to control cabomba through draw downs and subsequent drying out in Australia. In Lake Benella, Victoria, even a 3 month drawdown during summer was not enough to kill all cabomba plants (Dugdale et al., 2013). While long-term persistence of dried out fragments was not tested specifically in the present study, cabomba fragments protected in clumps of stranded vegetation and in moist substrate refugia in Lake Benella survived extended periods of time (Dugdale et al., 2013).

These data could form an integral part of a general model of aquatic plant dispersal. Such a model would also include factors such as initial fragment uptake, regeneration potential, the mechanics of establishment of fragments in a new environment and how habitat factors might influence establishment. For example, experiments should be carried out investigating if a diverse aquatic plant community could reduce establishment success of introduced fragments. A more general model of aquatic plant dispersal would be of great value to future management of aquatic weeds, as it would allow testing the effects of management scenarios on dispersal probability and also help predict the spread of aquatic weeds in the landscape.

Acknowledgments This research was funded by the Queensland Government and The Rural Industries Research and Development Corporation, RIRDC, Project No. PRJ006986. Cameron Clarke and Christine Perrett provided invaluable assistance with conducting the experiments. I wish to thank an anonymous reviewer for the constructive comments that assisted greatly in improving this manuscript. 


\section{References}

Barnes, M. A., C. L. Jerde, D. Keller, W. L. Chadderton, J. G. Howeth \& D. M. Lodge, 2013. Viability of aquatic plant fragments following desiccation. Invasive Plant Science and Management 6: 320-325.

Barrat-Segretain, M.-H. \& B. Cellot, 2007. Response of invasive macrophyte species to drawdown: the case of Elodea sp. Aquatic Botany 87: 255-261.

Bickel, T. O., 2012. Ecology of the submersed aquatic weed Cabomba caroliniana in Australia. In Eldershaw, V. (ed.), Eighteenth Australasian Weeds Conference, Melbourne, 8-11 October 2012. Weed Society of Victoria: 21-24.

Dugdale, T. M., K. L. Butler, D. Clements \& T. D. Hunt, 2013. Survival of cabomba (Cabomba caroliniana) during lake drawdown within mounds of stranded vegetation. Lake and Reservoir Management 29: 1-7.

Evans, C. A., D. L. Keltin, K. M. Forrest \& L. E. Steblen, 2011. Fragment viability and rootlet formation in Eurasian watermilfoil after desiccation. Journal of Aquatic Plant Management 49: 57-62.

Hogsden, K. L., E. P. S. Sager \& T. C. Hutchinson, 2007. The impacts of the non-native macrophyte Cabomba caroliniana on littoral biota of Kasshabog Lake, Ontario. Journal of Great Lakes Research 33: 497-504.

Jacobs, M. J. \& H. J. Macisaac, 2009. Modelling spread of the invasive macrophyte Cabomba caroliniana. Freshwater Biology 54: 296-305.

Jerde, C. L., M. A. Barnes, E. K. DeBuysser, A. Noveroske, W. L. Chadderton \& D. M. Lodge, 2012. Eurasian watermilfoil fitness loss and invasion potential following desiccation during simulated overland transport. Aquatic Invasions 7: 135-142.

Johnson, L. E., A. Ricciardi \& J. T. Carlton, 2001. Overland dispersal of aquatic invasive species: a risk assessment of transient recreational boating. Ecological Applications 11: 1789-1799.

Johnstone, I. M., B. T. Coffey \& C. Howard-Williams, 1985. The role of recreational boat traffic in interlake dispersal of macrophytes: a New Zealand case study. Journal of Environmental Management 20: 263-279.

Les, D. \& L. Mehrhoff, 1999. Introduction of nonindigenous aquatic vascular plants in southern New England: a historical perspective. Biological Invasions 1: 281-300.

Lockwood, J. L., P. Cassey \& T. Blackburn, 2005. The role of propagule pressure in explaining species invasions. Trends in Ecology \& Evolution 20: 223-228.

Lockwood, J. L., P. Cassey \& T. M. Blackburn, 2009. The more you introduce the more you get: the role of colonization pressure and propagule pressure in invasion ecology. Diversity and Distributions 15: 904-910.

Lodge, D. M., S. Williams, H. J. MacIsaac, K. R. Hayes, B. Leung, S. Reichard, R. N. Mack, P. B. Moyle, M. Smith, D.
A. Andow, J. T. Carlton \& A. McMichael, 2006. Biological invasions: recommendations for U.S. policy and management. Ecological Applications 16: 2035-2054.

Lowe, S., M. Browne, S. Boudjelas \& D. P. M., 2000. 100 of the worlds worst invasive alien species: a selection from the global invasive species database. Invasive Species Specialist Group, Auckland.

Mack, R. N., D. Simberloff, W. M. Lonsdale, H. Evans, M. Clout \& F. A. Bazzaz, 2000. Biotic invasions: causes, epidemiology, global consequences, and control. Ecological Applications 10: 689-710.

Mackey, A. P. \& J. T. Swarbrick, 1997. The biology of Australian weeds 32. Cabomba caroliniana Gray. Plant Protection Quarterly 12: 154-165.

McAlarnen, L. A., M. A. Barnes, C. L. Jerde \& D. M. Lodge, 2012. Simulated overland transport of Eurasian watermilfoil: survival of desiccated plant fragments. Journal of Aquatic Plant Management 50: 147-149.

McCracken, A., J. D. Bainard, M. C. Miller \& B. C. Husband, 2013. Pathways of introduction of the invasive aquatic plant Cabomba caroliniana. Ecology and Evolution 3: 1427-1439.

Ørgaard, M., 1991. The genus Cabomba (Cabombaceae) - a taxonomic study. Nordic Journal of Botany 11: 179-203.

Puth, L. M. \& D. M. Post, 2005. Studying invasion: have we missed the boat? Ecology Letters 8: 715-721.

R Core Team, 2013. R: a language and environment for statistical computing, 3.0.1 ed. R Foundation for Statistical Computing, Vienna.

Rahel, F. J., 2007. Biogeographic barriers, connectivity and homogenization of freshwater faunas: it's a small world after all. Freshwater Biology 52: 696-710.

Rothlisberger, J. D., W. L. Chadderton, J. McNulty \& D. M. Lodge, 2010. Aquatic invasive species transport via trailered boats: what is being moved, who is moving it, and what can be done. Fisheries 35: 121-132.

Smart, R. M. \& J. W. Barko, 1985. Laboratory culture of submersed freshwater macrophytes on natural sediments. Aquatic Botany 21: 251-263.

van Valkenburg, J. L. C. H., R. M. M. Roijackers \& R. Leonard, 2011. Cabomba caroliniana Gray in the Netherlands. 3rd International Symposium on Weeds and Invasive Plants, Ascona, Oct 2011: 6.

Vitousek, P. M., D. M. D'Antonio, L. L. Loope \& R. Westbrooks, 1996. Biological invasions as global environmental change. American Scientist 84: 468-478.

Wilson, C. E., S. J. Darbyshire \& R. Jones, 2007. The biology of invasive alien plants in Canada. 7. Cabomba caroliniana A. Gray. Canadian Journal of Plant Science 87: 615-638.

Wilson, J. R. U., E. E. Dormontt, P. J. Prentis, A. J. Lowe \& D. M. Richardson, 2009. Something in the way you move: dispersal pathways affect invasion success. Trends in Ecology \& Evolution 24: 136-144. 